\title{
Nonenzymatic NADH-Dependent Reduction of Keggin- Type 12-Tungstocobaltate(III) in Aqueous Medium
}

\author{
PRABLA KUMARI, ALAKA DAS, DILLIP KUMAR BARAL, \\ A. K. PATTANAIK ${ }^{\S}$ and P. MOHANTY* \\ Department of Chemistry, Utkal University \\ Bhubaneswar, 751004, Orissa, India \\ ${ }^{\S}$ Department of Chemistry \\ Khalikot Autonomous College, Berhampur, India \\ pmohantyuu@gmail.com
}

Received 14 October 2010; Accepted 17 December 2010

\begin{abstract}
The kinetics of the electron transfer reaction of NADH with 12-tungstocobaltate(III) has been studied over the range $5.07 \leq 10^{4}$ [NADH] $\leq 15.22 \mathrm{~mol} \mathrm{dm}^{-3}, 7.0 \leq \mathrm{pH} \leq 8.0$ and $20 \leq \mathrm{t} \leq 35^{\circ} \mathrm{C}$ in aqueous medium. The electron transfer reaction showed first-order dependence each in $[\mathrm{NADH}]_{\mathrm{T}}$ and [12-tungstocobaltate(III) $]_{\mathrm{T}}$. The products of the reaction were found to be $\mathrm{NAD}^{+}$and 12-tungstocobaltate(II). The activation parameters $\Delta \mathrm{H}^{\#}\left(\mathrm{~kJ} \mathrm{~mol}^{-1}\right)$ and $\Delta \mathrm{S}^{\#}\left(\mathrm{JK}^{-1} \mathrm{~mol}^{-1}\right)$ of the electron transfer reactions were found to be $64.4 \pm 1.8$ and $-48.86 \pm 6.0$. Negative value of $\Delta \mathrm{S}^{\#}$ is an indicative of an ordered transition state for the electron transfer reaction.
\end{abstract}

Keywords: Electron transfer, NADH, 12-Tungstocobaltate(III), Nonenzymatic

\section{Introduction}

Nicotinamide adenine dinucleotide (NADH) is a coenzyme. It is oxidized to $\mathrm{NAD}^{+}$in presence of enzymes. In metabolism $\mathrm{NAD}^{+}$is involved in redox reactions, carrying electrons from one reaction to other. The coenzyme is therefore found in two forms in cells: $\mathrm{NAD}^{+}$as an oxidizing agent and NADH as a reducing agent. The redox potential of the NAD $\mathrm{NADH}^{+} \mathrm{NAuple}$ is -0.32 volts $^{1}$, which makes NADH a strong reducing agent. The reaction is reversible ${ }^{8}$, this means the coenzyme can continuously cycle between $\mathrm{NAD}^{+}$and NADH forms. Studies on the electron transfer reactions of NADH and its synthetic analogues have been reported ${ }^{2-8}$. Reduction of methemoglobin ${ }^{9}$, orthovanadate and vanadyl sulphate $^{10}$, ferric siderophores ${ }^{11}$ and heteropolytungstovanadophosphates ${ }^{12}$ by NADH has been reported.

The oxidant Keggin type 12-tungstocobaltate(III) $\left(\mathrm{Co}^{\mathrm{III}} \mathrm{W}_{12} \mathrm{O}_{40}{ }^{5-}\right.$ or $\left.\mathrm{Co}^{\mathrm{III}} \mathrm{W}^{5-}\right)$ cluster has a reduction potential of $1.0 \mathrm{~V}^{13}$, hence it can accept electrons from NADH. The above cluster is known for photochemical hydrogen generation and is involved in multielectron reduction 
processes $^{14-16}$. The redox behavior of the above cobalt cluster with few biomolecules like ascorbic $\operatorname{acid}^{17}$, glutathione ${ }^{18}$, citric acid ${ }^{19}, D L$-methionine ${ }^{20}$ and cystine ${ }^{21}$ have been investigated. In order to examine the redox behavior of 12-tungstocobaltate(III), its reaction with NADH has been investigated.

\section{Experimental}

$\left[\mathrm{Co}^{\mathrm{III}} \mathrm{W}_{12} \mathrm{O}_{40}\right]^{5-}$ was prepared by the reported method ${ }^{17}$ and was characterized spectrophotometrically ${ }^{23}$ (at $388 \mathrm{~nm} \varepsilon_{388}=1150 \pm 2 \mathrm{dm}^{-3} \mathrm{~mol}^{-1} \mathrm{~cm}^{-1}$ ). The chemicals used were of A.R grade and doubly distilled water was used throughout the experiment. The electron transfer reaction was studied at $\mathrm{pH}=7.5 \pm 0.01$ using a pre-standardised Elico (India) digital $\mathrm{pH}$ meter equipped with glass electrode. The $\mathrm{pH}$ of the solution was maintained using phosphate buffer.

The absorbance measurements for the kinetic studies were done using CECIL CE 7200 UV-VIS scanning spectrophotometer equipped with CE 2024 thermoelectric controller. Reaction progress was monitored at $380 \mathrm{~nm}$, pseudo first order conditions were maintained throughout the runs by using large ( $\geq$ five fold) excess of [NADH]. The rate constants $\left(\mathrm{k}_{\mathrm{obs}}\right)$ were obtained from the slope of $-\ln \left(\mathrm{A}_{\mathrm{t}}-\mathrm{A}_{\infty}\right)$ versus ' $\mathrm{t}$ ' (min) plots (Figure 1).

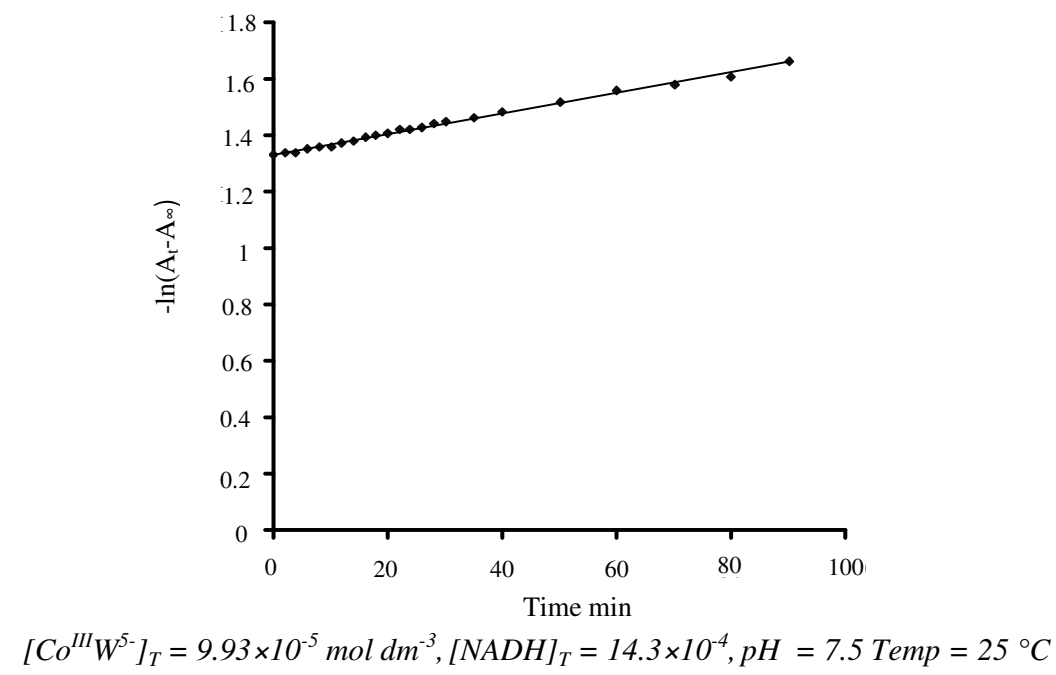

Figure 1. Determination of $\mathrm{k}_{\mathrm{obs}}$ value

$$
-\ln \left(A_{t}-A_{\infty}\right)=k_{\text {obs }} t+C
$$

Where $A_{t}$ and $A_{\infty}$ are the absorbance of the reaction mixture at time ' $t$ ' and at equilibrium respectively. The reported rate data represented as an average of duplicate runs were reproducible to within $\pm 3 \%$. The correlation coefficient of the plots used to determine $\mathrm{k}_{\mathrm{obs}}$ were found to be 0.99 in most cases.

\section{Results and Discussion}

$\mathrm{Co}^{\mathrm{III}} \mathrm{W}_{12} \mathrm{O}_{40}{ }^{5-}$ has absorbance maxima at $388 \mathrm{~nm}$ and on mixing with $\mathrm{NADH}$ the peak is found to be decrease with time (Figure 2) with simultaneous increase of new peaks at $625 \mathrm{~nm}$ (Figure 3) due to the formation of $\mathrm{Co}^{\mathrm{II}} \mathrm{W}_{12} \mathrm{O}_{40}{ }^{6-}$ and a peak at $260 \mathrm{~nm}$ (Figure 5) due to the formation of $\mathrm{NAD}^{+}$is observed. The decrease of absorbance at $380 \mathrm{~nm}$ is followed for the reduction of $\mathrm{Co}^{\mathrm{III}} \mathrm{W}_{12} \mathrm{O}_{40}{ }^{5-}$ by $\mathrm{NADH}$. 


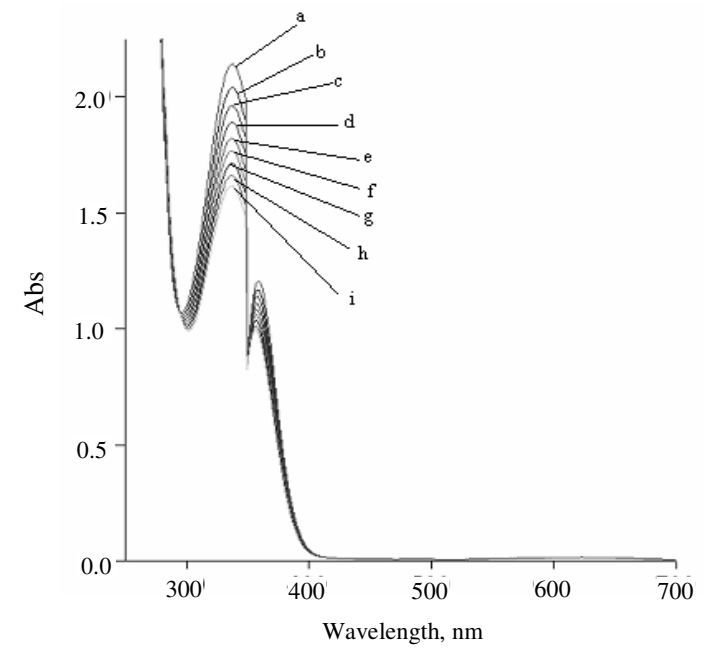

$\left[\mathrm{Co}^{\text {III }} \mathrm{W}^{5-}\right]_{T}=9.93 \times 10^{-5} \mathrm{~mol} \mathrm{dm}{ }^{-3},[\mathrm{NADH}]_{T}=5.07 \times 10^{-5} \mathrm{~mol} \mathrm{dm} m^{-3}, \mathrm{pH}=7.5, \mathrm{Temp}=30^{\circ} \mathrm{C}, a=o \mathrm{~min} ; \quad b$ $=10 \mathrm{~min} ; c=20 \mathrm{~min} ; d=30 \mathrm{~min} ; e=40 \mathrm{~min}, f=50 \mathrm{~min} ; g=60 \mathrm{~min} ; h=70 \mathrm{~min} ; i=80 \mathrm{~min}$

Figure 2. Overlay scan of reaction mixture with respect to time

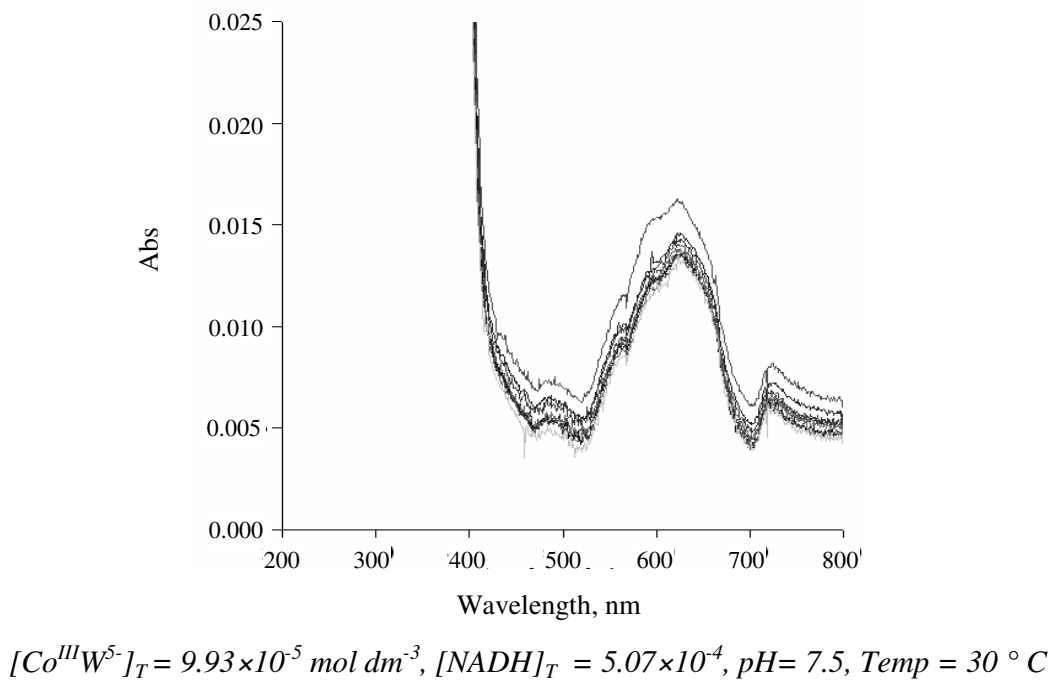

Figure 3. Scan of reaction mixture with respect to time showing $\left[\mathrm{Co}^{\mathrm{III}} \mathrm{W}\right]^{6-}$ formation

\section{Effect of [NADH] on reaction rate}

The effect of varying $[\mathrm{NADH}]$ on the reaction rate was studied at fixed $\mathrm{pH}$ (7.5) and between $20-35{ }^{\circ} \mathrm{C}$. The concentration of $\mathrm{Co}^{\mathrm{III}} \mathrm{W}^{5-}$ was kept constant and $10^{4}[\mathrm{NADH}]$ was changed from 5.07 to $15.22 \mathrm{~mol} \mathrm{dm}^{-3}$.

The plot of $\mathrm{k}_{\mathrm{obs}} / \mathrm{s}^{-1}$ vs. $[\mathrm{NADH}]_{\mathrm{T}}$ is linear at four different temperatures $\left(20-35{ }^{\circ} \mathrm{C}\right)$ (Figure 4). This fact indicates that the reaction is first order with respect to $[\mathrm{NADH}]_{\mathrm{T}}$. Since the second order rate constant does not change appreciably at a given temperature (Table. 1). The overall order of the electron transfer reaction is two. Hence the order with respect to the $\left[\mathrm{Co}^{\mathrm{III}} \mathrm{W}^{5-}\right]_{\mathrm{T}}$ must be one. 
Table 1. Values of $\mathrm{k}_{\mathrm{obs}}$ at different temperatures $\left[\mathrm{Co}^{\mathrm{III}} \mathrm{W}^{5-}\right]_{\mathrm{T}}=9.93 \times 10^{-5} \mathrm{~mol} \mathrm{dm} \mathrm{dm}^{-3}$ and $\mathrm{pH}=7.5$

\begin{tabular}{ccccc}
\hline $10^{4}[\mathrm{NADH}]$ & \multicolumn{4}{c}{$10^{4} \mathrm{k}_{\mathrm{obs}} / \mathrm{s}^{-1}$} \\
\cline { 2 - 5 } $\mathrm{mol} \mathrm{dm}^{-3}$ & $293 \mathrm{~K}$ & $298 \mathrm{~K}$ & $303 \mathrm{~K}$ & $308 \mathrm{~K}$ \\
\hline 5.07 & 0.33 & 0.50 & 0.89 & 1.42 \\
7.61 & 0.43 & 0.71 & 1.15 & 1.86 \\
10.15 & 0.57 & 0.90 & 1.34 & 2.01 \\
14.31 & 0.77 & 1.16 & 1.66 & 2.40 \\
15.22 & 0.82 & 1.22 & 1.75 & 2.51 \\
$\mathrm{k}_{2(\text { average) }}$ & $0.057 \pm 0.004$ & $0.088 \pm 0.0079$ & $0.1380 \pm 0.0254$ & $0.212 \pm 0.050$ \\
$\mathrm{~mol}^{-1} \mathrm{dm}^{3} \mathrm{~s}^{-1}$ & & $\Delta H^{\#}=64.4 \pm 1.8 \mathrm{~kJ} \mathrm{~mol}^{-1}, \Delta S^{\#}=-48.86 \pm 6.0 \mathrm{JK}^{-1} \mathrm{~mol}^{-1}$
\end{tabular}

\section{Rate dependence on $\mathrm{pH}$}

At $298 \mathrm{~K}$ with $\left[\mathrm{Co}^{\mathrm{III}} \mathrm{W}^{5-}\right]_{\mathrm{T}}=9.93 \times 10^{-5}$ and $[\mathrm{NADH}]_{\mathrm{T}}=5.07 \times 10^{-4} \mathrm{~mol} \mathrm{dm}^{-3}$, the $\mathrm{pH}$ was varied from 7.0 to 8.0 using phosphate buffer $\left(\mathrm{KH}_{2} \mathrm{PO}_{4}+\mathrm{Na}_{2} \mathrm{HPO}_{4}\right)$ and $10^{4} \mathrm{k}_{\text {obs }}\left(\mathrm{s}^{-1}\right)$ was found to be fairly constant $(1.11 \pm 0.38)$. The electron transfer reaction does not show any $\mathrm{pH}$ dependence in the $\mathrm{pH}$ range 7.0 to 8.0. The electron transfer reaction could not be studied at higher $\mathrm{pH}$ because oxidant cobalt(III) clusters will undergo base hydrolysis.

\section{Rate dependence on temperature}

The electron transfer reaction was followed in the temperature range $20-35{ }^{\circ} \mathrm{C}$. The oxidant concentration was kept constant at $9.93 \times 10^{-5} \mathrm{~mol} \mathrm{dm}^{-3}$ and the reductant $\mathrm{NADH}$ concentration was varied from $5.07 \times 10^{-4}$ to $15.22 \times 10^{-4} \mathrm{~mol} \mathrm{dm}^{-3}$. The $\mathrm{k}_{\mathrm{obs}}$ was found to increase with increase in temperature (Figure 4). The second order rate constant $10^{2} \mathrm{k}_{2}$ changed from $5.7 \pm 0.4$ to $21.2 \pm 5.0$ when temperature was changed from $20-35{ }^{\circ} \mathrm{C}$. The values of $\Delta \mathrm{H}^{\#}$ and $\Delta \mathrm{S}^{\#}$ were calculated using eyring equation and were found to be $64.4 \pm 1.8 \mathrm{~kJ} \mathrm{~mol}^{-1}$ and $-48.86 \pm 6.0 \mathrm{JK}^{-1} \mathrm{~mol}^{-1}$. The negative value of activation entropy indicates an ordered transition state for the electron transfer reaction.

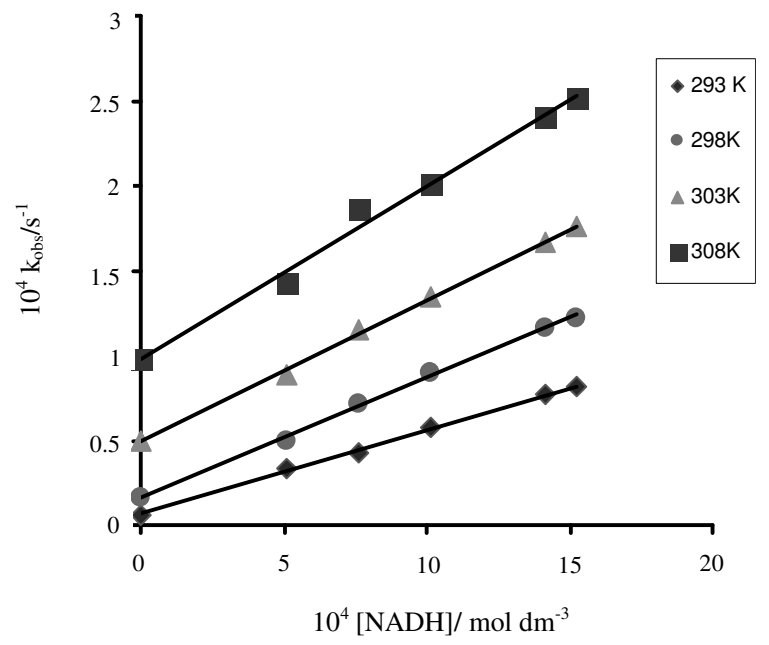

Plots of $10^{4} k_{\text {obs }}$ versus $10^{4}[\mathrm{NADH}]$ at various temperatures

Figure 4. Rate dependence on temperature 


\section{Polymerization study}

The participation of free radicals was examined as follows. The reaction mixture, to which a known quantity of acrylonitrile scavenger had been added initially, was kept in an inert atmosphere for $5 \mathrm{~h}$. When the reaction mixture was diluted with methanol, a white precipitate resulted. The above experiment supports the formation of free radical. Blank experiments with either $\left[\mathrm{Co}^{\mathrm{III}} \mathrm{W}\right]^{5-}$ or $\mathrm{NADH}$ with acrylonitrile did not give polymerization under the same conditions as those used for the reaction mixture.

\section{Stoichiometry and characterization of product}

The stoichiometry of the reaction was studied at $30{ }^{\circ} \mathrm{C}$ where $\left[\mathrm{Co}^{\mathrm{III}} \mathrm{W}^{5-}\right]_{\mathrm{T}}$ was kept constant at $9.93 \times 10^{-5} \mathrm{~mol} \mathrm{dm}^{-3}$ and $[\mathrm{NADH}]_{\mathrm{T}}$ at $5.07 \times 10^{-4} \mathrm{~mol} \mathrm{dm}^{-3}$. Formation of a peak at $260 \mathrm{~nm}$ after 3 half lives (Figure 5) indicates the formation of $\mathrm{NAD}^{+}$. The formation of a peak at $625 \mathrm{~nm}$ (Figure 3) indicates the formation of $\left[\mathrm{Co}^{\mathrm{II}} \mathrm{W}\right]^{6-}$. The stoichiometry of the reaction can be written as

$$
2\left[\mathrm{Co}^{\mathrm{III}} \mathrm{W}\right]^{5-}+\mathrm{NADH} \longrightarrow 2\left[\mathrm{Co}^{\mathrm{II}} \mathrm{W}\right]^{6-}+\mathrm{NAD}^{+}+\mathrm{H}^{+}
$$

Basing on the above observations and experimental results, the probable mechanism may be delineated as in Scheme 1.

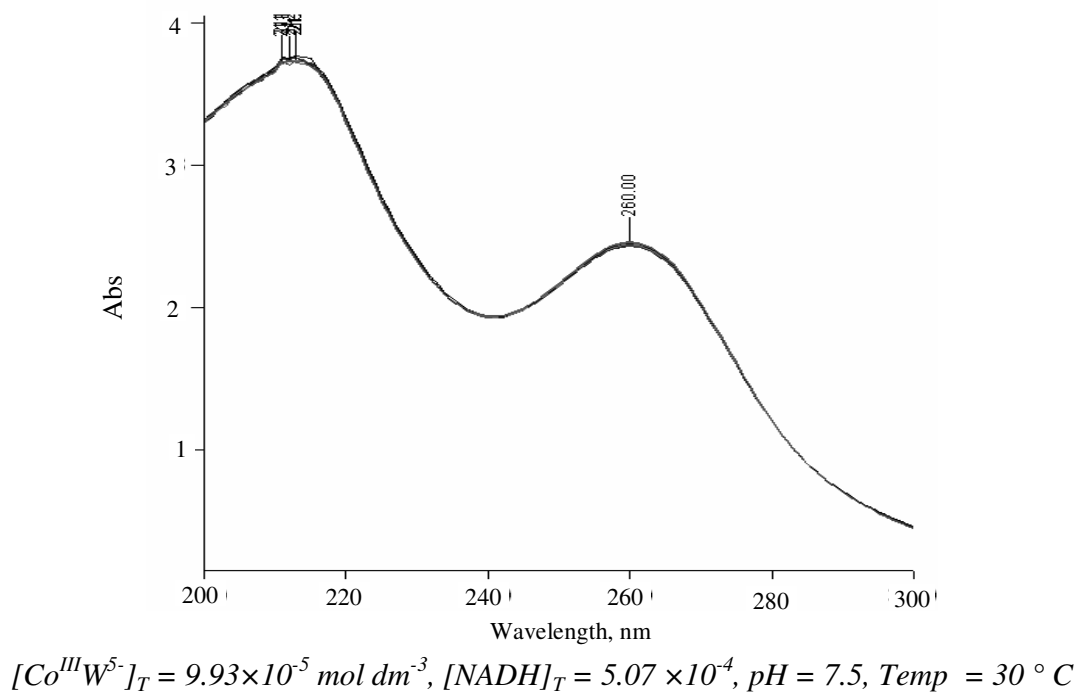

Figure 5. Scan of reaction mixture with respect to time showing $\mathrm{NAD}^{+}$formation after $24 \mathrm{~h}$.

$$
\begin{aligned}
& \mathrm{NADH}+\left[\mathrm{Co}^{\mathrm{III}} \mathrm{W}\right]^{5-} \underset{\mathrm{k}_{-1}}{\stackrel{\mathrm{k}_{1}}{\underset{\mathrm{k}}{\rightleftarrows}}} \mathrm{NADH}^{++}+\left[\mathrm{Co}^{\mathrm{II}} \mathrm{W}\right]^{6-} \\
& \mathrm{NADH}^{+}+\mathrm{H}_{2} \mathrm{O} \underset{\mathrm{k}_{-2}}{\stackrel{\mathrm{k}_{2}}{\leftrightarrows}} \mathrm{NAD}+\mathrm{H}_{3} \mathrm{O}^{+} \\
& \mathrm{NAD}^{\cdot}+\left[\mathrm{Co}^{\mathrm{III}} \mathrm{W}\right]^{5-} \underset{\mathrm{k}_{-3}}{\stackrel{\mathrm{k}_{3}}{\rightleftarrows}} \mathrm{NAD}^{+}+\left[\mathrm{Co}^{\mathrm{II}} \mathrm{W}\right]^{6-}
\end{aligned}
$$

Scheme 1. The rate law for the electron transfer reaction can be written as Rate $=\mathrm{k}_{2}$ $[\mathrm{NADH}]\left[\mathrm{Co}^{\mathrm{III}} \mathrm{W}^{5-}\right] \mathrm{k}_{2}=2^{\text {nd }}$ order rate constant 
The above mechanism involves multiple electron-proton-electron transfer steps. Initially an electron is transferred from NADH to $\left[\mathrm{Co}^{\mathrm{III}} \mathrm{W}\right]^{5-}$ producing $\mathrm{NADH}^{++}$and $\left[\mathrm{Co}^{\mathrm{II}} \mathrm{W}\right]^{6-}$. The solvent water molecule abstracts the proton from $\mathrm{NADH}^{+}$to produce $\mathrm{NAD}$. For such a mechanism either electron transfer from NADH to $\left[\mathrm{Co}^{\mathrm{III}} \mathrm{W}\right]^{5-}$ or proton transfer from $\mathrm{NADH}^{+}$to water may be rate limiting step. As reported earlier ${ }^{12,22}$ the initial electron transfer step appears to be the rate limiting step in the oxidation of NADH by $\left[\mathrm{Co}^{\mathrm{III}} \mathrm{W}\right]^{5-}$.

\section{References}

1. Campbell M K and Farrell S O, Biochemistry, $6^{\text {th }}$ Edn., Thomson Brooks/cole, Canada, 2008.

2. Rao A V S and Ramasarma T, Biochem Biophys Acta, 2000, 1474, 321-330.

3. Shi X and Dalal N S, Arch Biochem Biophys., 1993, 307, 336-341.

4. Patole M S, Gullapalli S and Ramasharma T, Free Rad Res Commun., 1988, 4, 201.

5. $\quad$ Patole M S, Gullapalli S and Ramasarma T, J Neurochem., 1988, 51, 491.

6. Khandke L, Gullapalli S, Patole M S and Ramasarma T, Arch Biochem and Biophys., 1986, 244, 742-749.

7. Ramasarma T, Mac Keller W and Crane F L, Indian J Biochem Biophys., 1980, 17, 1638.

8. Vijaya S and Ramasarma T, J Inorg Biochem., 1984, 20, 247-254.

9. Tomoda A, Yubisui T, Tsuji A and Yoneyama Y, J Biol Chem., 1979, 254, 3119-3123.

10. Keller J R, Coulombe A R, Sharma P R, Grover A T and Piette H L, Arch Biochem Biophys., 1989, 271, 40-48.

11. Adjimani J P and Owusu E, J Inorg Biochem., 1997, 66, 247-252.

12. Sami P and Rajasekaran K, J Chem Sci., 2009, 121, 155-161.

13. Eberson L, J Am Chem Soc., 1983, 105, 3192.

14. Ioannidis A and Papaconstantinou E, Inorg Chem., 1985, 24, 439.

15. Pope T M and Papaconstantinou E, Inorg Chem., 1967, 6, 1147.

16. Pope T M and Varga Jr M G, Inorg Chem., 1966, 5, 1249.

17. Amjad Z, Brodovctch C J and McAuley A, Can J Chem., 55, 1977, 3581.

18. Ayoko A G and Olatunji A M, Inorg Chim Acta, 1983, 80, L15-L17.

19. Saha K S, Ghosh C M and Banerjee P, Int J Chem Kinet., 2004, 20, 699.

20. Satpathy K P, Dash C G, Acharya S and Mohanty P, J Indian Chem Soc., 2006, 83, 891.

21. Satpathy P K, Dash G C and Mohanty P, Indian J Chem., 2008, 47A, 1199-1203.

22. Keita B, Essaadi K, Nadjo L, Contant R and Justum Y, J Electro Anal Chem., 1996, 404, 271.

23. Rasmussen G P and Brubaker H L, Inorg Chem., 1964, 3, 977. 


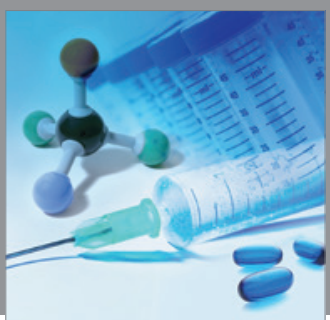

International Journal of

Medicinal Chemistry

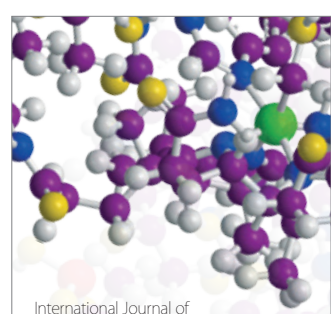

Carbohydrate Chemistry

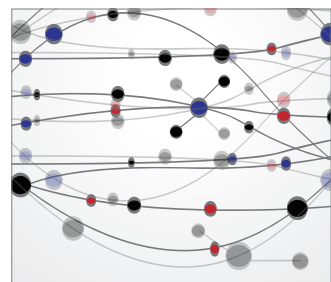

The Scientific World Journal
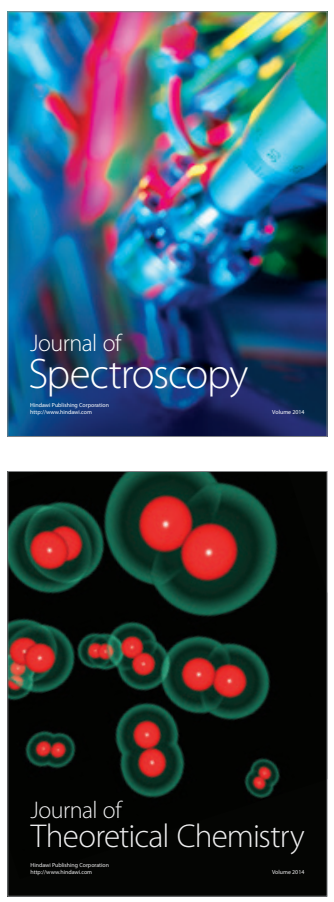
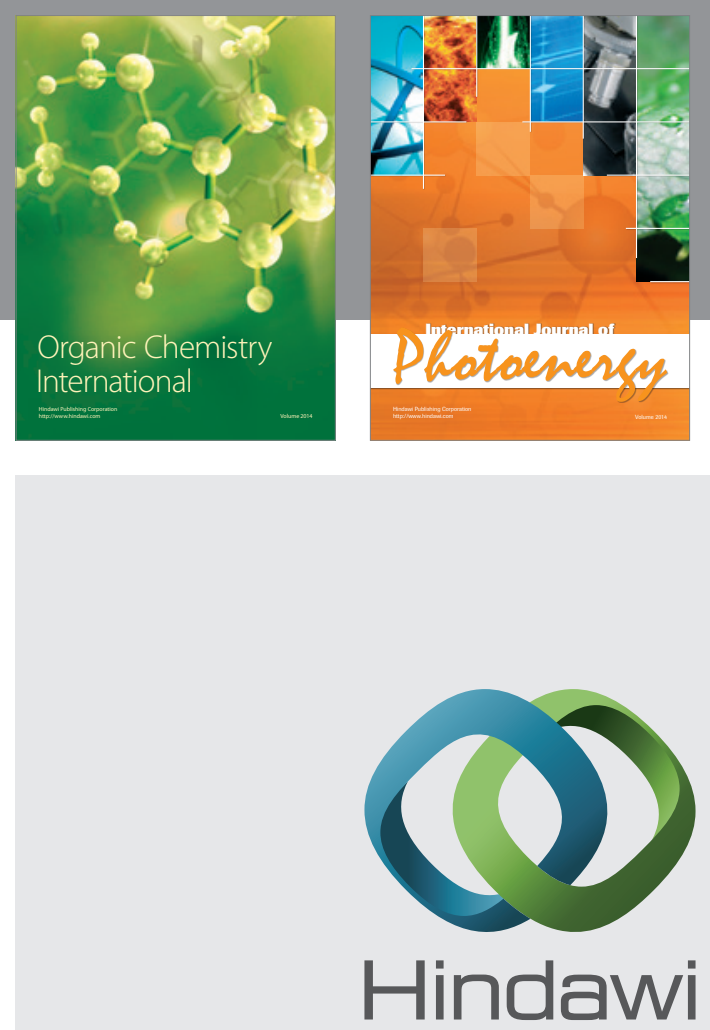

Submit your manuscripts at

http://www.hindawi.com
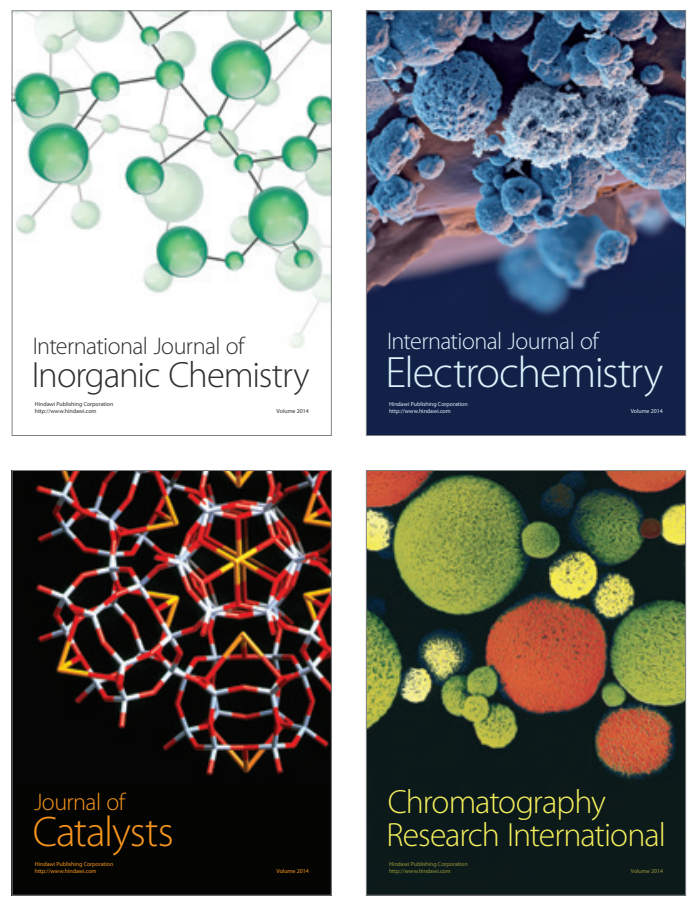
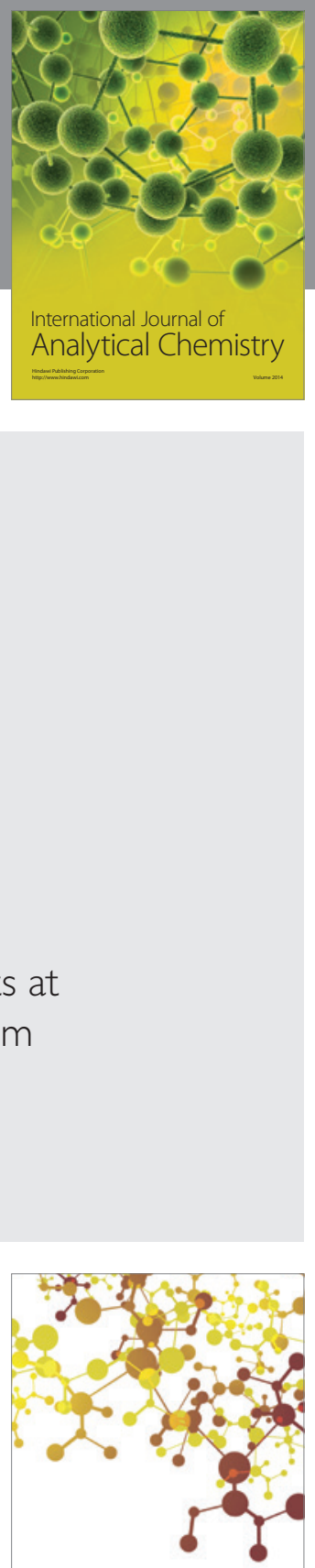

Journal of

Applied Chemistry
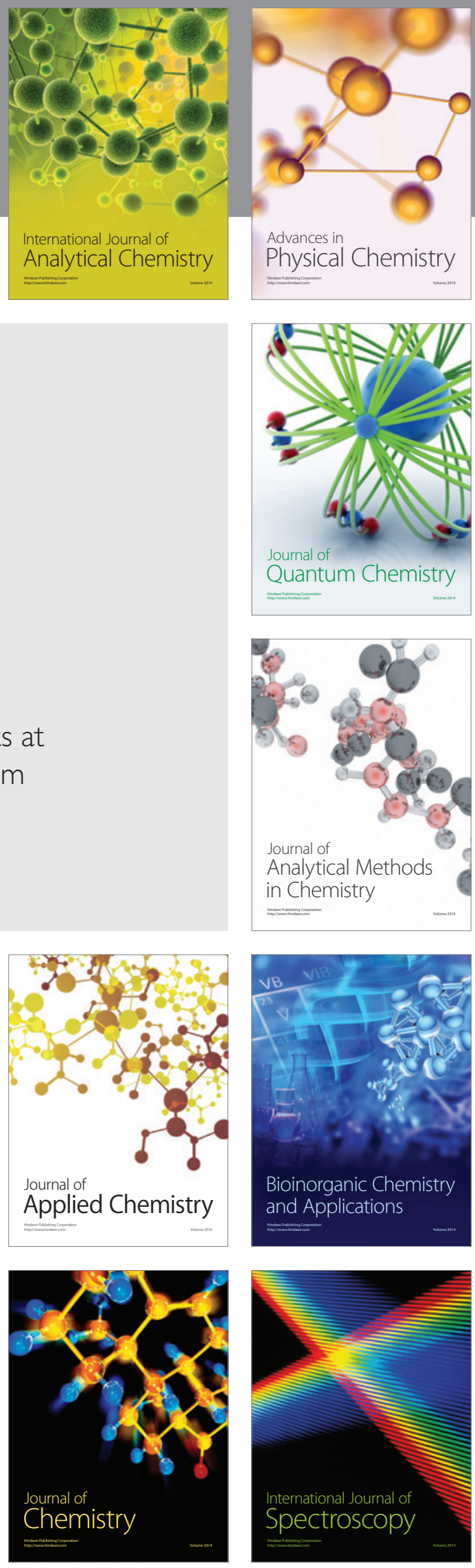